Images In...

\title{
Solitary Langerhans cell histiocytosis of the external auditory canal
}

\author{
Andleeb Abrari, ${ }^{1}$ Vandana Bakshi \\ ${ }^{1}$ Department of Histopathology, Max Super Specialty Hospital, New Delhi, India; \\ 2Department of ENT, New Delhi, India
}

Correspondence to Andleeb Abrari, abrariand@gmail.com

\section{DESCRIPTION}

The manifestations of Langerhans cell histiocytosis (LCH) are legion in both local and systemic variants. About $15-61 \%$ patients with LCH have otologic involvement; this manifestation is more frequent in children with multisystem disease and a primary manifestation in 5-25\% of patients. Among otologic lesions, solitary external ear $\mathrm{LCH}$, as the only site of clinically non-progressive disease, is very rare. ${ }^{12}$

This case illustrates an instance of external ear canal LCH, initially managed without success as an eczematous lesion/seborrhoeic dermatitis for 8 months in a 3-year-old child; refractoriness of the lesion forced a biopsy, which on histopathology was diagnosed as LCH (figures 1 and 2).

The patient was found to have no bone lesion and no other focus on systemic survey.

In children, this situation underpins the ineffable import of histological evaluation in all refractory/recalcitrant cases of 'eczematoid' lesions and a necessary honing of the suspicion index towards the possibility of $\mathrm{LCH}$ in such lesions. ${ }^{3}$

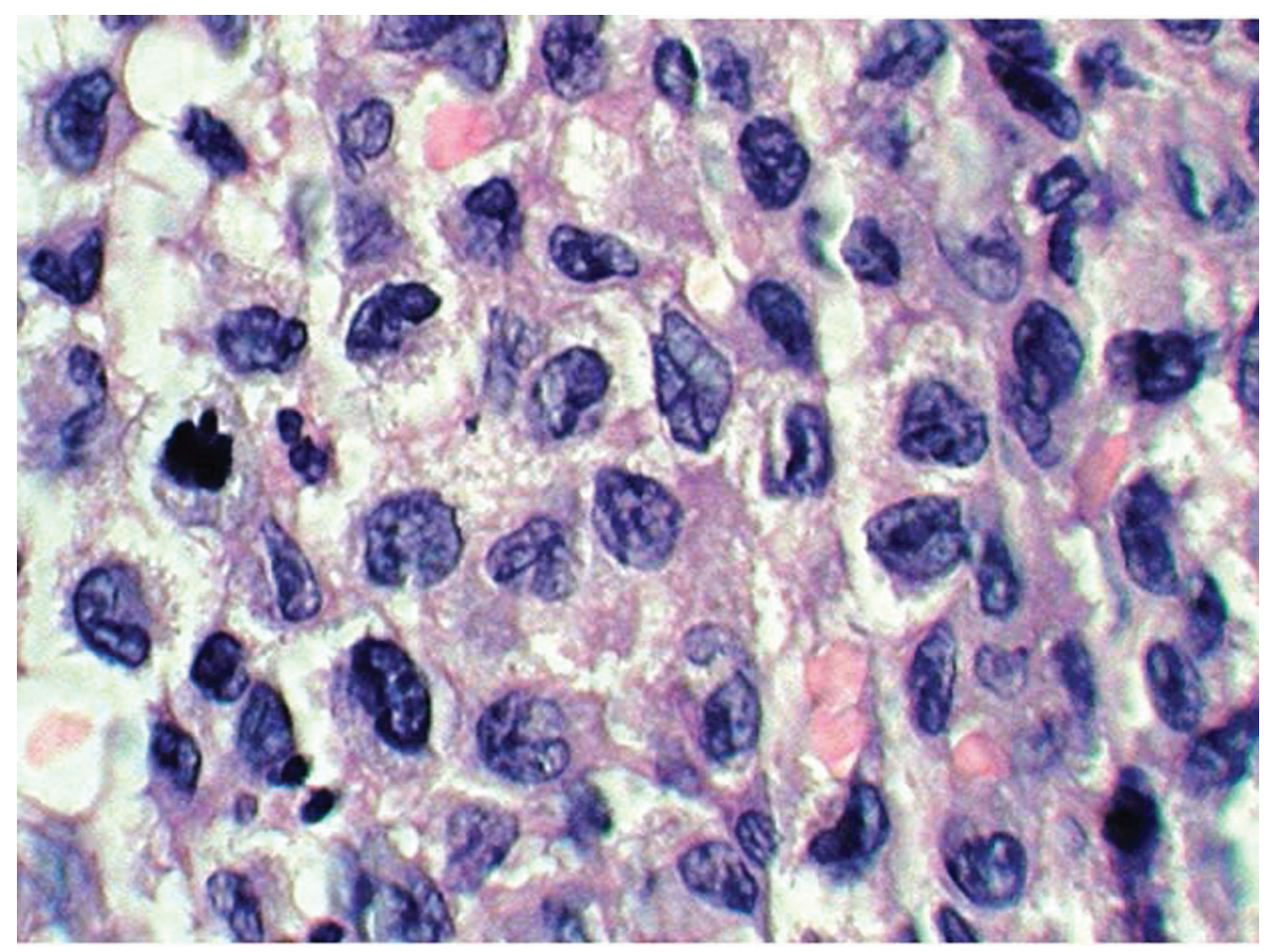

Figure 1 Polygonal cells with moderately abundant amphophilic to eosinophilic cytoplasm and irregularly contoured nuclei with longitudinal nuclear grooves pathognomonic for Langerhans cells. 


\section{BMJ Case Reports}

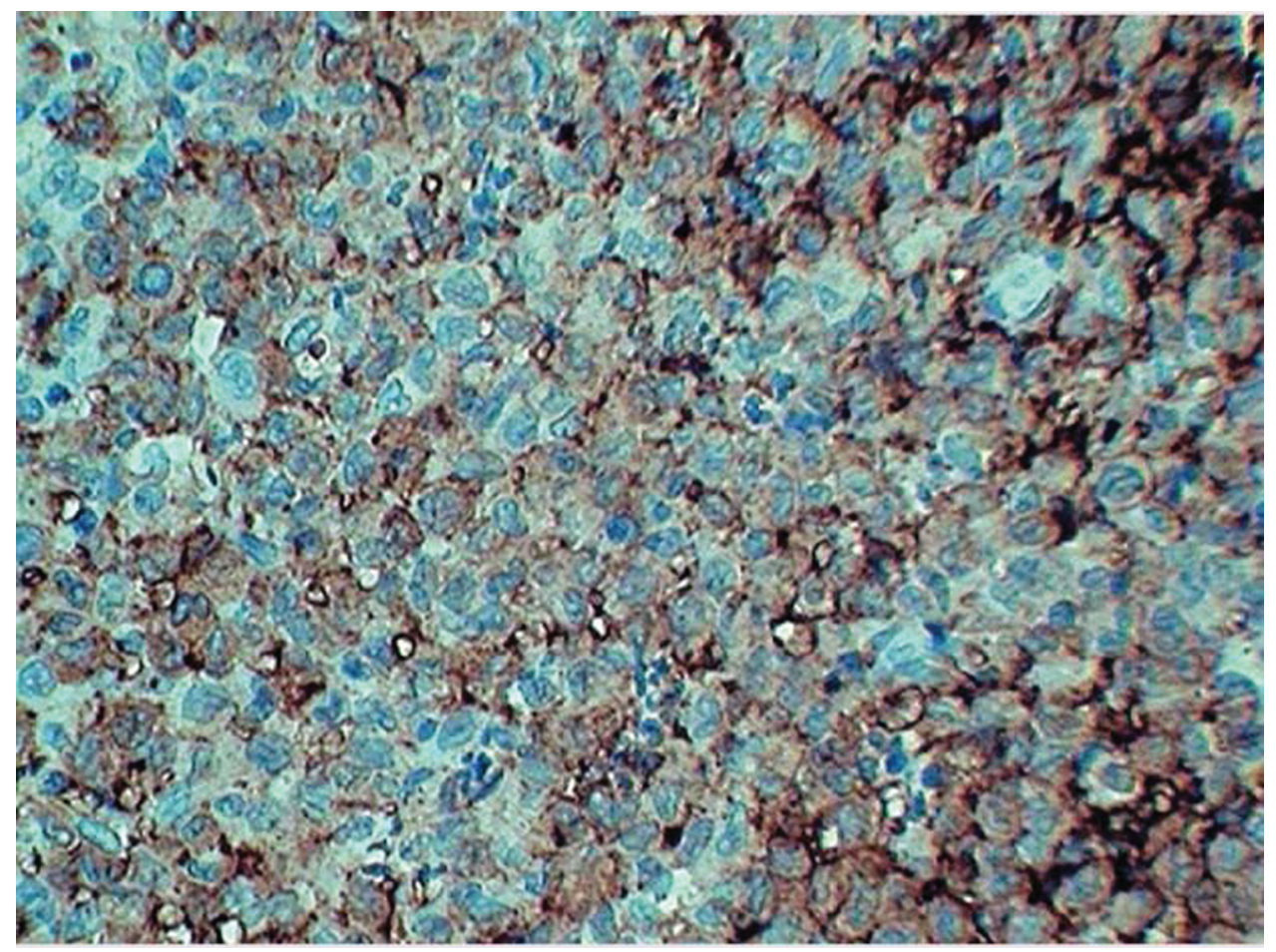

Figure 2 CD1a immune expression confirms these cells as Langerhans cells.

Competing interests None.

Patient consent Obtained.

\section{REFERENCES}

1. McCaffrey TV, McDonald TJ. Histiocytosis $X$ of the ear and temporal bone: review of 22 cases. Laryngoscope 1979;89:1735-42.
2. Hermans R, De Foer B, Smet MH, et al. Eosinophilic granuloma of the head and neck: CT and MRI features in three cases. Pediatr Radiol 1994;24:33-6.

3. D'Ambrosio N, Soohoo S, Warshall C, et al. Craniofacial and intracranial manifestations of langerhans cell histiocytosis: report of findings in 100 patients. AJR Am J Roentgenol 2008;191:589-97.

This pdf has been created automatically from the final edited text and images.

Copyright 2011 BMJ Publishing Group. All rights reserved. For permission to reuse any of this content visit http://group.bmj.com/group/rights-licensing/permissions.

BMJ Case Report Fellows may re-use this article for personal use and teaching without any further permission.

Please cite this article as follows (you will need to access the article online to obtain the date of publication).

Abrari A, Bakshi V. Solitary Langerhans cell histiocytosis of the external auditory canal. BMJ Case Reports 2011;10.1136/bcr.10.2010.3447, date of publication

Become a Fellow of BMJ Case Reports today and you can:

- Submit as many cases as you like

- Enjoy fast sympathetic peer review and rapid publication of accepted articles

- Access all the published articles

- Re-use any of the published material for personal use and teaching without further permission

For information on Institutional Fellowships contact consortiasales@bmjgroup.com

Visit casereports.bmj.com for more articles like this and to become a Fellow 